\title{
Ocorrência de Latrocimex spectans Lent (Hemiptera, Cimicidae, Latrocimicinae) no Paraná, Brasil ${ }^{1}$
}

\author{
Gustavo Graciolli ${ }^{2}$ \\ Marcelo O. Bordignon ${ }^{2}$ \\ Maurício O. Moura ${ }^{2}$
}

Latrocimex spectans Lent, 1941 um percevejo ectoparasita encontrado apenas no morcego ictiófago Noctilio leporinus (Linnaeus, 1758). LENT (1941) quando descreveu a espécie, baseou-se em exemplares coletados em um ninho de $N$. leporinus, numa fazenda às margens do Rio São Francisco, Mato Grosso.

WEIDNER (1958) e USINGER (1966) registraram a ocorrência de L. spectans em Trinidad e Ilha Marajó (Maranhão), respectivamente.

Em 23.V.1998, o segundo autor e S.S. Franco capturaram uma fêmea de $N$. leporinus, por meio de uma rede de neblina (mist-net) armada na área do Iate Clube Caiobá (Caiobá, município de Matinhos, Paraná) e, sobre o seu corpo, encontraram um exemplar macho de L. spectans. Esta ocorrência amplia a distribuição geográfica da espécie para o Sul do Brasil e registra-se também, pela primeira vez, a captura de um exemplar em hospedeiro em plena atividade de vôo. Todas as coletas anteriores do percevejo foram realizadas em abrigos de $N$. leporimus.

\section{REFERÊNCIAS BIBLIOGRÁFICAS}

LENT, H. 1941. Latrocimex spectans n.gen., n.sp., parasita de morcegos no Brasil (Hemiptera, Cimicidae). Rev. Brasil. Biol. 1 (1): 41-46.

USINGER, R.L. 1966. Monograph of Cimicidae (Hemiptera -Heteroptera). Lanham, Entomological Society of America, The Thomas Say Foundation, Vol. $7,585 \mathrm{p}$.

WEIDNER, H. 1958. Die auf Fledermäusen parasitierenden Insketen mit besonderer Berücksichtigung der in Deutschland vorkommenden Arten. Narch. naturwiss. Mus. Aschaffenburg 59: 1-88.

Recebido em 20.VIII.1998; aceito em 14.V.1999.

1) Contribuição número 1142 do Departamento de Zoologia, Universidade Federal do Paraná.

2) Departamento de Zoologia, Universidade Federal do Paraná. Caixa Postal 19020, 81.531-990 Curitiba, Paraná, Brasil.

E-mail: mingau@bio.ufpr.br 